\title{
SYSTEMATIC GEOLOGICAL MAPPING IN 1979 IN THE PEARY LAND REGION, NORTH GREENLAND
}

\author{
General introduction to the present collection of papers
}

\author{
Niels Henriksen
}

The second season of a three year systematic field mapping programme in the Peary Land region, north of $c$. lat. $81^{\circ} \mathrm{N}$ and east of $c .40^{\circ} \mathrm{W}$, was carried out in June-August 1979. The aim of the programme is to produce a 1:500 000 map sheet of eastern North Greenland and to investigate the geological framework of the region.

This report presents the main results from the second year's geological field investigations and in addition some results of laboratory investigations on last year's material. A similar report on the first year's results was published as GGU report no. 88, 1979.

The expedition in 1979 numbered 34, comprising 12 geological two-man parties and supporting personnel. The geological parties were divided into several working groups. Two parties worked in the Precambrian platform area between Wandel Dal and Danmark Fjord (fig. 1), four parties in the Lower Palaeozoic platform sequence in southern Peary Land, and three parties mapped the mainly Lower Palaeozoic sequence in the fold belt area north of Frederick E. Hyde Fjord. Quaternary geological investigations were carried out by one team and another team sampled for palaeomagnetic investigations. All parties collected stream sediments for a geochemical survey while one team carried out a special sampling programme.

The second year's work expanded and refined the mapping initiated in 1978 in the Proterozoic - Lower Palaeozoic platform area and a series of detailed investigations of certain lithological, palaeontological and stratigraphical aspects of the succession were carried out. In general the mapping in the area between Danmark Fjord and Frederick E. Hyde Fjord is now complete. Mapping in the fold belt area north of Frederick E. Hyde Fjord was initiated in 1979, and a reconnaissance cross section through the western part of Kronprins Christian Land was carried out in preparation for the general mapping of this area.

The tent base camp established in 1978 at the mouth of Jørgen Brønlund Fjord again served as operation centre for two small helicopters and a small STOL aircraft. Transport of the whole expedition to and from Greenland was carried out with help from the Royal Danish Air Force who airlifted material and personnel from Danmark to Station Nord and return. As in 1978 the expedition was carried out in cooperation with a surveying group from the Geodetic Institute, Copenhagen, who worked mainly in the region west of Peary Land establishing ground control points for a new topographic map of North Greenland.

The report contains 19 contributions from the individual participating geologists, geophysicists and their collaborators. A preliminary general geological map of the region was published as a fold-out map with the 1978 report (GGU rapport no. 88). The localities for the present collection of contributions are indicated on fig. 1 . 